\title{
本州各地より採集したイネドロオイムシの 殺虫剂感受性
}

下松明雄, 石野洋二, 大津悠一, 伊藤春男*

(株)日本特殊農薬製造農薬研究所

*(株)日本特殊農薬製造仙台出張所

（昭和 53 年 12 月 18 日受理）

\section{Geographical Variations of Insecticidal Susceptibility of the Rice Leaf Beetle}

\author{
Akio Kudamatsu, Yoji Ishino, Yuichi Otsu and Haruo Ito* \\ Agricultural Chemicals Research Institute, Nihon Tokushu Noyaku Seizo Co., Ltd., \\ Hino, Tokyo 191, Japan \\ *Tohoku Branch Office, Nihon Tokushu Noyaku Seizo Co., Ltd., \\ Sendai, Miyagi 980, Japan
}

\begin{abstract}
The susceptibility of adults and larvae of the rice leaf beetle, Lema oryzae, to propoxur was determined by topical application. Also, comparison of susceptibility of overwintered female beetles collected from 17 spots in 10 prefectures to propoxur, carbaryl, phenthoate and phosmet were made. No significant differences of the susceptibility levels to tested insecticides were observed among the beetles from various localities. As averages of $\mathrm{LD}_{50}$ values of propoxur $(0.0023 \mu \mathrm{g})$, carbaryl $(0.0095 \mu \mathrm{g})$, and phenthoate $(0.10 \mu \mathrm{g})$ determined in this study were very similar to those which reported by Inoue \& Okuyama in 1969, the resistance of this insect to organophosphorus and carbamate insecticides was not found.
\end{abstract}

\section{緒言}

イネの害虫イネドロオイムシ (Lema oryzae) に対し てカーバメート系殺虫剤, とくに propoxur が高い殺虫 活性をもち ${ }^{1,2,6)}$ ，その粒剤の育苗箱および本田施用が有 効であることが知られている ${ }^{9,10)}$. 過去においてこの害 虫の殺虫剤抵抗性は $\gamma$-BHCについて各地で報告されて いるが ${ }^{3 \sim 6)}$ ， その殺虫力の検定は防除効果の 低下の後に 実施され，それ以前の成績が得られておらず，抵抗性の 発達と $\gamma-\mathrm{BHC}$ の投下量との関連や地域差の原因が追跡 されていない7). また $\gamma$-BHC と DDT, 有機燐剤, カ 一バメート剂との間に交差抵抗性は認められず2)，rBHC の使用中止とともにこの抵抗性問題は自然に解消 したものの，その後使用される有機燐剤，カーバメート 剂にも薬剂抵抗性が出現する可能性はあり，その予知な らびに解消の努力が必要であることが，その当時すでに
指摘されている ${ }^{8)}$.

筆者らは propoxur のイネドロオイムシに対する作用 特性を検討するなかで10), 薬剂感受性の現状調査および 抵抗性が出現した場合の比較対照とするために，4種の 薬剤について各地から越冬成虫を採集して局所施用法に よる効力検定を行なったので報告する.

\section{材料および方法}

感受性検定にはカーバメート系殺虫剂として propoxur (純度 99.9\%), carbaryl (同 99.9\%)，有機燐剤として phenthoate（同 96.3\%)， phosmet（同 95.8\%)を用い， これらの原体から数段階の濃度のアセトン溶液を調製し て局所施用を行なった。

供試虫には, 各地より本田飛来期前後の越冬成虫を採 集し雌雄を分けて $15^{\circ} \mathrm{C}$ の温度条件下でイネ葉を給餌し て飼青したものを用い, Table 1 に示した雌雄等の比較 
試験には新潟県長岡市長倉町において 1976 年 5 月 26 日 に採集した越冬成虫と, それをバイオトロンにて水稲に 産卵させ飼育して得られた 4 踰幼虫および新成虫を用い た。

局所施用は, 成虫の場合炭酸ガスで麻酔した後, 薬剤 のアセトン溶液を Burkard 社製 Arnold hand microapplicator を用いて腹部腹面に滴下し，幼虫は虫糞を除去 した後腹部背面に滴下した. 滴下量は $0.5 \mu \mathrm{l}$ として溶 液濃度によって施用量の段階を設定し，処理頭数は 20 頭ずつとした．処理後供試虫をプリンカップ（直径 6.5 $\mathrm{cm}$, 深さ $4 \mathrm{~cm}$ のポリプロピレン製) にイネの葉片とと もに収容し，48 時間後に生死虫を計数して得られた死 虫率から Probit 法により $\mathrm{LD}_{50}$ 值を算出した. なお試験 は処理から調查まで， $20^{\circ} \mathrm{C}$ の恒温条件下で行なった.

各地の供試虫の採集場所と採集年月日は以下のとおり である.地図上の位置は Fig. 1 に示した。

1）青森県南津軽郡浪岡町
大釈迦

2） " 三戸郡三戸町

3）秋田県秋田市繫沢

4） " 秋田市大平大曲

5）岩手県宮古市花輪

6） " 和賀郡東和町田

7） " 西磐井郡花泉町 永井

8）山形県山形市中里

9） I 山形市休石

10）宮城県気仙沼市後沢

11） " 桃生郡河北町

12）福島県東白河郡棚倉町

13）新潟県長岡市長倉町

14） " 刚羽郡西山町二 田

15）福井県福井市寮町

16）山梨県中巨摩郡敷島町
1978 年 6 月 8 日 ( 6 月 13 日) $*$ II 6 月 9 日

(6月13日) 1/ 6 月 7 日 (6月11日)

II 6 月 7 日

(6月 11 日)

II 6 月 8 日 (6月11日)

II 6 月 9 日

(6月11日)

II 6 月 6 日

(6月 8 日)

1/ 6 月 6 日

(6月 8 日)

I" 6 月 6 日

(6月 8 日)

I" 6 月 6 日

( 6 月 8 日)

1977 年 6 月 15 日

(6月16日)

II 6 月 1 日

(6月 10 日)

1976 年 5 月 26 日

(5月 28 日)

1977 年 5 月 17 日

(5月 24 日)

II 6 月 3 日

( 6 月 16 日)

1976 年 6 月 19 日

( 6 月 21 日)
17）千葉県夷隅郡大多喜町 1977 年 5 月 13 日 小土呂

( 5 月 24 日)

*：（）は局所施用処理月日

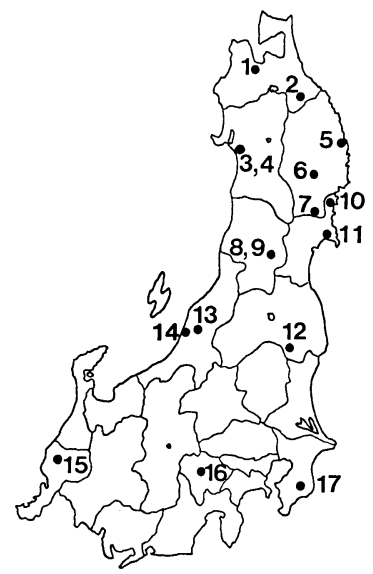

Fig. 1 Localities of collected insects.

\section{結果および考察}

propoxur に対する越冬成虫雌雄, 新成虫, 幼虫の局 所施用による $\mathrm{LD}_{50}$ 值を Table 1 に示した. 越冬成虫 では, 雌は $0.0029 \mu \mathrm{g}$ で雄の $0.0013 \mu \mathrm{g}$ にくらべ 2.2 倍の数值が得られ，新成虫（雌雄の区別をしていない） は $0.0027 \mu \mathrm{g}$ で, 越冬前後において感受性に大きな変化 は認められなかった。しかし 4 踚幼虫は $0.036 \mu \mathrm{g}$ で成 虫より 10 倍以上の $\mathrm{LD}_{50}$ 值が得られた。

Table 1 Toxicity of propoxur against rice leaf beetles.

\begin{tabular}{cccc}
\hline \multicolumn{4}{c}{ LD $_{50}(\mu \mathrm{g} /$ insect $)$} \\
\hline \multicolumn{3}{c}{ Adult } & $\begin{array}{c}\text { Larva } \\
\text { 4th instar }\end{array}$ \\
\cline { 1 - 2 } Overwintered & Emerged & \\
\hline 0.0013 & 0.0029 & 0.0027 & 0.036 \\
\hline
\end{tabular}

propoxur と現在使用中の防除薬剂 carbaryl, phenthoate, phosmet に対する，10 県 17 地点から採集したイネ ドロオイムシ越冬雌成虫の感受性を Table 2 に示した. 各薬剤の感受性レベルは, 全地域で propoxur 0.0012 $0.0046 \mu \mathrm{g}$ (平均 $0.0023 \mu \mathrm{g}$ ), carbaryl $0.0076 \sim 0.013 \mu \mathrm{g}$ (平均 $0.0095 \mu \mathrm{g}$ ), phenthoate $0.055 \sim 0.20 \mu \mathrm{g}$ (平均 $0.10 \mu \mathrm{g}$ ), phosmet $0.045 \sim 0.19 \mu \mathrm{g}$ (平均 $0.10 \mu \mathrm{g}$ ) の 範囲でほぼ一定しており，とくに地域差は認められなか った. 1969 年に井上・奥山が北海道の鷹栖町，富良野 
Table 2 Comparative $\mathrm{LD}_{50}$ values of insecticides against overwintered rice leaf beetles collected from various places in Japan.

\begin{tabular}{|c|c|c|c|c|c|}
\hline \multicolumn{2}{|c|}{ Locality of collected insects } & \multicolumn{4}{|c|}{$\mathrm{LD}_{50}(\mu \mathrm{g} /$ 우 beetle) } \\
\hline Prefecture & City or Town & Propoxur & Carbaryl & Phenthoate & Phosmet \\
\hline 1. Aomori & Namioka & 0.0025 & 0.013 & 0.20 & 0.13 \\
\hline 2. Aomori & Sannohe & 0.0012 & 0.011 & 0.055 & 0.077 \\
\hline 3. Akita & Tsunagizawa & 0.0023 & 0.0095 & 0.10 & 0.082 \\
\hline 4. Akita & Taihei-Omagari & 0.0016 & 0.0071 & 0.11 & 0.14 \\
\hline 5. Iwate & Miyako & 0.0017 & 0.0088 & 0.068 & 0.068 \\
\hline 6. Iwate & Towa & 0.0017 & 0.0082 & 0.14 & 0.066 \\
\hline 7. Iwate & Hanaizumi & 0.0034 & 0.0088 & 0.11 & 0.045 \\
\hline 8. Yamagata & Nakazato & 0.0026 & 0.0084 & 0.077 & 0.060 \\
\hline 9. Yamagata & Yasumiishi & 0.0034 & 0.013 & 0.13 & 0.12 \\
\hline 10. Miyagi & Kesennuma & 0.0046 & 0.0087 & 0.11 & 0.098 \\
\hline 11. Miyagi & Kahoku & 0.0016 & & & \\
\hline 12. Fukushima & Tanagura & 0.0017 & 0.008 & & \\
\hline 13. Niigata & Nagaoka & 0.0029 & & & \\
\hline 14. Niigata & Nishiyama & 0.0031 & 0.012 & 0.060 & 0.19 \\
\hline 15. Fukui & Fukui & 0.0012 & & & \\
\hline 16. Yamanashi & Shikishima & 0.0014 & & & 0.13 \\
\hline 17. Chiba & Otaki & 0.0014 & 0.0076 & 0.071 & 0.077 \\
\hline
\end{tabular}

$\mathrm{LD}_{50}$ determination were based on mortality counts for 48 hours at $20^{\circ} \mathrm{C}$ following topical application of the insecticidal solutions in $0.5 \mu \mathrm{l}$ of acetone to individual ventral abdomens under carbon dioxide anesthesia.

市，名寄市で採集した新成虫を用いて局所施用による効 力検定を行なっているが2)，これによると propoxur $0.0016 \sim 0.0032 \mu \mathrm{g}$, carbaryl $0.0099 \sim 0.012 \mu \mathrm{g}$, phenthoate $0.17 \sim 0.19 \mu \mathrm{g}$ という $\mathrm{LD}_{50}$ 值で，筆者らの越冬 成虫の数值もこれによく一致している. 北海道では 1967 年に $\gamma$-BHC の効力低下に対して, phenthoate, carbaryl 等の使用が推奖されているが，その他の地域で も 10 年以上これらの薬剤が使用されているにもかかわ らず，現在抵抗性出現の徵候が認められなかったことは 興味深い.

\section{要 約}

propoxur の局所施用法によるイネドロオイムシの $\mathrm{LD}_{50}$ 值は, 越冬成虫の雙で $0.0029 \mu \mathrm{g}$, 雄で 0.0013 $\mu \mathrm{g}$ ，新成虫では $0.0027 \mu \mathrm{g}, 4$ 齢幼虫では $0.036 \mu \mathrm{g}$ で あった。

イネドロオイムシの薬剤感受性の現状を調査するため に，本州の 10 県 17 地点から越冬成虫を採集し，局所施 用法により $\mathrm{LD}_{50}$ 值を求めた. その結果 propoxur は $0.0012 \sim 0.0046 \mu \mathrm{g}$, carbaryl は $0.0076 \sim 0.013 \mu \mathrm{g}$, phenthoate は $0.055 \sim 0.20 \mu \mathrm{g}$, phosmet は $0.045 \sim$
$0.19 \mu \mathrm{g}$ の範囲内で，とくに地域差は認められず，いず れの薬剤についても抵抗性は見いだされなかった。

本稿を終えるにあたり，供試虫の採集等に多大なご援 助を賜わった各県農業試験場および防除所の各位に深く 感謝の意を表する.

\section{引用 文 献}

1）井上 寿：農薬研究 17 (3)，5（1971）

2）井上 寿 - 奥山七郎：道立上川 -中央農試成績書 44 (1970)

3）井上 寿 - 奥山七郎：北日本病虫研報 $\mathbf{2 0}, 73$ (1969)

4）渡辺忻悦：北日本病虫研報 21，43（1970）

5）江村一雄 - 小鴆昭雄 - 遠藤賢治：北陸 病虫研 報 18, 51 (1970)

6）嘉藤省吾： 北陸病虫研報 18，54（1970）

7）堀口治夫：植物防疫 21（11），459（1967）

8）堀口治夫：植物防疫 24（11），461（1970）

9）阿部 禎：農及園 51（4），526（1976）

10）小山正一・江村一雄・小嶋昭雄・大津悠一・石野 洋二・下松明雄：第 3 回日本農薬学会講演要旨, p. 308,1978 